\title{
Impact of Sago Crop Commercialization Programs on Gender Roles of Melanau Communities in Sarawak, Malaysia
}

\author{
Siti Zanariah Ahmad Ishak ${ }^{1}$, Malia Taibi ${ }^{2}$ \& Ahmad Nizar Yaakub ${ }^{2}$ \\ ${ }^{1}$ Faculty of Social Sciences, Universiti Malaysia Sarawak \\ ${ }^{2}$ Faculty of Language and Communication, Universiti Malaysia Sarawak \\ Correspondence: Siti Zanariah Ahmad Ishak. E-mail: aizana@unimas.my
}

Received: August 29, 2017

doi:10.5539/ass.v13n12p35
Accepted: October 2, $2017 \quad$ Online Published: November 28, 2017

URL: https://doi.org/10.5539/ass.v13n12p35

\begin{abstract}
Melanau men are known for their significant roles in the cultivation of sago palm as smallholder farmers while the women take charge of processing sago-based food products. Melanau sago farmers play important roles in maintaining their rural livelihood as the ethnic minority group in the northwest coastal communities of Sarawak, Malaysia. In an attempt to contribute to the corpus of knowledge on Melanau gender roles and their unique farming practices, this paper adapts gender relations framework in order to assess the impact of sago commercialization programs that were established by the local authority since 1980s. The findings revealed that the changes of traditional gender roles among men and women are influenced by gender relations factors i.e. gender division of labour, access to or control of resources and household decision making. In addition, sago production promises a greater prospect of moving away from low to high commercial level of production only if human capital that makes sago crop difficult to commercialize are tackled in the Melanau community. This suggests that more attention to human factors is needed when authorities formulate policies relating to commercialization program.
\end{abstract}

Keywords: rural women, smallholder farmers, gender relations, commercialization programs, Melanau communities

\section{Introduction}

Researchers posit that in the developing countries, commercialization of indigenous agricultural commodities is regarded as a prerequisite for achieving social and economic development of rural communities (Belcher \& Schreckenberg, 2007; Carletto, et al., 2017). More importantly, commercialization programs directed at gender mainstreaming promote increased participation of men and women in the production, processing and marketing of agricultural commodities at local and international markets (Rubin \& Manfre, 2014; Forsythe, Posthumus \& Martin, 2016). The recognition that rural communities served as hub for agricultural resources and the continuous interventions of government and development agencies in revitalising rural economy not only will benefit rural households but also will lead to economic growth and development (Scott, 2014; Millstone, Thompson, \& Brooks, 2009). In the context of the sago cultivation sector in Sarawak, Malaysia, men and women assist one another in sago value chain, whereby men are in charge of sago palm cultivation and maintenance because of their physical strength and tedious nature of the work involved while the women involve in food production, processing and marketing as well as assisting their men in the farm (Barton, 2012; Hirschman, 2016).

Initially sago development programs established by the government of Sarawak are designed to facilitate the sago production of the rural Melanau smallholder farmers. Concerns over the yield of sago which is inconsistent and low compared with its economic potential has led to the establishment of more agencies by the government in initiating the sago commercialization programs. In promoting the value of sago, the crop is given an image as "the 21st Century Crop" in which its potential is expected to contribute to higher export revenue for Sarawak as well as to diversify sago-based food products. In addition, sago is being promoted as the crop that is indigenous to Sarawak where the sago-based food products are promoted for tourism purposes because of the Melanau cultural identity is generally attached to sago. The downstream activities of using sago starch which involved women are for local consumption and the preservation of Melanau food cultural identity has been established in the areas of processing and marketing.

The commercialization programs require the engagement of the Melanau smallholders' household in the farming and production of sago-based food products who are willing to transcend from low production to commercial level. This change requires the actors to adopt new ideas of farm management, farming practices and their commitment. However, these new ideas, are viewed and misunderstood by many farmers to be contradicted with the traditional farming beliefs and practices. The Melanau community had highly regarded the sago palm tree which permeates through their daily economic and socio-cultural activities. However, the unique traditional sago farming practice which is considered as their part-time job and 'after retirement job' poses a challenge toward maximizing production.

The objectives of this research are two folds. Firstly, it is to examine gender roles of Melanau men and women in sago production while capitalising on gender relations. Secondly, the study is to describe the processes and impact of sago 
commercialization on gender roles. The research analysis on the qualitative data will form the basis for assessing the productivity of smallholder farmers and sago-based food processors capitalising on the commercialization programs initiated by the government.

\section{Literature Review}

\subsection{Gender Roles and Commercialization}

We operationalize gender roles as the daily practices perform by male and female farmers in relation to their work. Anthropologists who studied gender relations on many Southeast Asian peasant communities have established the concept of "complementarity" in describing the roles of men and women (King \& Wilder, 2003, p. 263). The concept refers to a division in the roles of husband and wife in the organization of acquiring and managing the family's economic resources. For example, complementarity roles of men and women were evident in the Malay fishing community (Firth, 1966; Carsten 1997), Malay rice cultivation community (Winzeler, 1974), and Iban rice cultivation community (Mashman, 1991). Firth (1966) contended that fishing was the primary economic activity in generating food and cash for Malay families in Kelantan where the husband fishes whilst the wife transforms the products into food and cash. Hence, the gender complementarity roles of men and women are extended here to conceptualize the rural Melanau sago smallholders' gender roles.

In the context of production, gender relations can be viewed as a historical, cultural and socially constructed phenomenon (Whatmore, 1991). Going by these components, gender relations is not fixed but it changes over the temporality of time base on process and content. For instance, the change phase depends on how fast women respond to government initiated program. Le (2009) reported that for almost 30 decades rural Vietnam women have showed their success in permeating the traditional male occupation of woodcarving. This is an indication that in terms of production, gender relations are constantly restructured to suit the processes involved in production which is usually characterised by factors relating to the internal and external context such as household development, technological innovations, change in government policies etc. Thus, the focus of this paper is to investigate production from the point of view of internal context which is household development.

The intensification of women's empowerment programs in agriculture promote improved food productivity and security. This development draws the attention of development organizations, policy makers and non-governmental organizations to empower women as important contributors to food production and ensure that inequality and discrimination against them is drastically reduced (World Bank, 2012). Though, gender structures are heterogeneous and multifaceted, in the sense that they are characterised by cultural norms and values which varies across various geographical locations (Mason, 2005). However, research revealed that in Southeast Asia, women benefit more through empowerment than their other counterparts in other developing countries (IFAD, 2013). They enjoyed relative liberty in terms of decision making unlike in many African countries where decisions are made for women by their husbands and other stakeholders. This fact signifies that they have a high level of control over their resources, assets and income (IFAD, 2013). Despite benefit acquired by women through commercialization program, it also disempowers them in production (Tsusaka et al., 2016). Research revealed that women are mostly side-lined in the supply of high quality agricultural products, which means that men take charge on such aspects of production (Herney, 2013).

\subsection{Conceptual Framework}

The gender relations framework in Figure 1, is an adaptation of the gender relations framework developed by van Eerdewijk and Danielsen (2015). It is a vital tool that can be used to determine gender division of labour, access to or control of resources, household decision making, norms and values (van Eerdewijk \& Danielsen, 2015). Taking into full cognizance that women are very important participants in many agricultural commodities value chains, the likelihood that commercialization programs will benefit or burden them needs to be put into consideration. As mentioned by Whatmore (1991), gender relations related to production and its analysis gives concrete information on how to determine the best approaches to promote commodity commercialization. Subsequent to the gender relations framework put together by van Eerdewijk and Danielsen (2015) we analyze the gender roles and the social dynamics attached to accessing production, processing and marketing. In many studies related to gender roles, especially those in agriculture and forestry, gender relations is hardly utilized to analyze the intricacy and changes that occur in men and women's roles. The Society of Sago Palm Studies (2015) explained that the most comprehensive and labour intensive aspects of sago production in the coastal area is usually done by men, though sometimes assisted by women. Nevertheless, apart from gender, factors related to culture, socioeconomic status, access to finance, demographic factors, raw material supply and market for products could explain the relationships and differences in the practices of actors in food production and its commercialization.

van Eerdewijk \& Danielsen (2015) argued that norm and values are one of the factors that existed in both three components (Household Decision Making, Division of Labour and Access to/Control of Resources) of gender relations that can be impacted when changes are introduced. However, in this research, we point out the prominence of norms and values which exist outside of the component factors, looking at its characteristics and the influence it have on the three components of gender relations which has not been particularly considered in studying gender roles in the Melanau communities. 


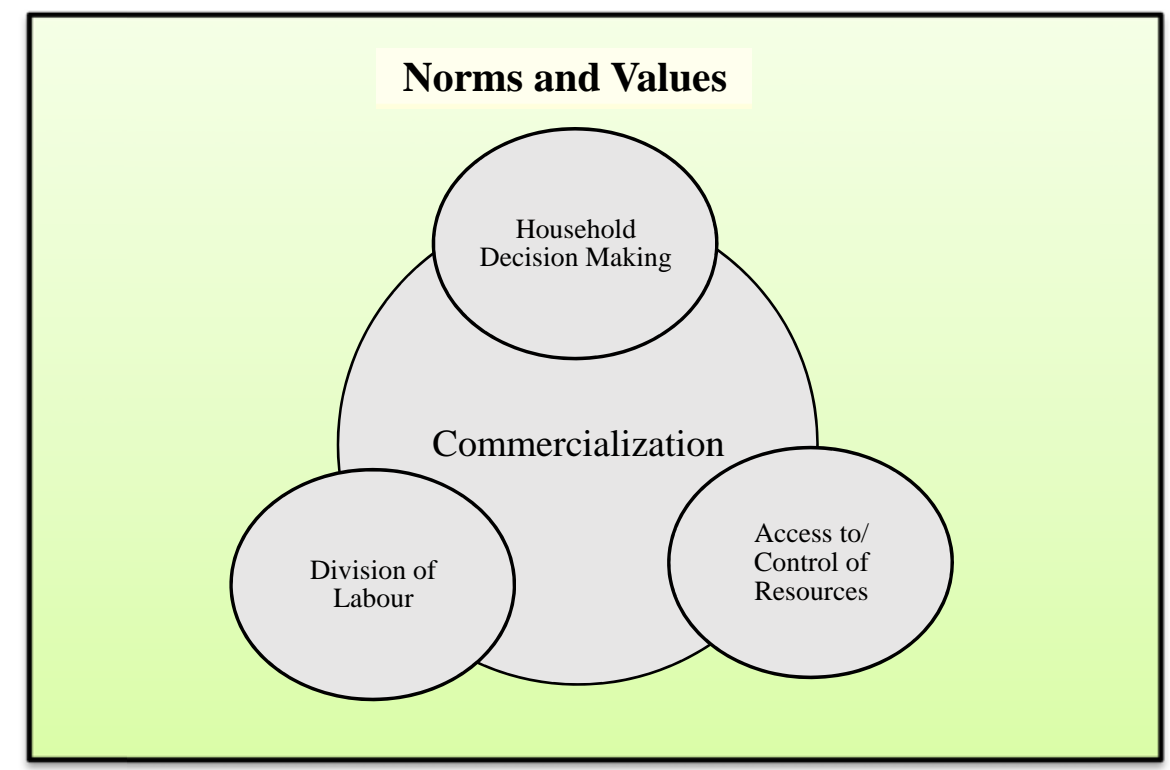

Figure 1. Gender Relations Framework (adapted from van Eerdewijk \& Danielsen 2015)

The expected relations, behaviours and traits associated to men and women are fashioned by cultural norms and values. This is due to culture is an independent factor that shapes peoples' activities within households and in the society at large. The function of gender among ethnic groups is a unifying value for the society. This is based on the cultural roles assigned to men and women. It is obvious in terms of gender division of labour, where women have their own clear roles different from that of men within a family circle or in the larger society as well as in terms of decision making and access to and control of resources. Though the explicit nature of gender relations differs in various communities, the universal arrangement is that women are dependents with less capacity to control resources, and restricted power to make decision for themselves and the society at large. However, gender roles are not static and they can be subjected to change over time because the society is also changing.

In the Melanau communities, changes in the production of sago are expected to lead to commercialization of the crop. However, the processes introduced to the farmers showed a diversion of their traditional practices which they are familiar with and have been transferred to them from generation to generation. Though it is a government policy, its impact on the values of the ethnic minority like the Melanau is of great concern to the people either to accept or resist the policy.

\section{Methodology}

Sago commercialization program's impact can be dynamically investigated if the beneficiaries tell their experiences on whether or not they had benefitted from it. Based on the conception that accepting programs are likely to distort gender roles and transform traditional practices are grounded on subjective personal experiences. Therefore, this study deployed a qualitative case approach to pursue the investigation on the impact of sago crop commercialization on gender roles in the Melanau coastal communities. In this regard, this study will highlight how commercialization programs are impacting on the sago producing communities whereby smallholder sago farmers who are mainly men and the sago-based food processors who are typically women. This study is conducted in Mukah Division, specifically in two locations: the coastal town of Mukah and the small town of Dalat situated along the Oya River (Figure 2). The fieldwork was conducted in four phases; two visits in 2015 and one visit each in 2016 and 2017. The length of stay in Mukah and Dalat for each visit ranged from five to seven days. The people observed and interviewed were smallholder sago farmers and their wives, the women involved in processing sago-based food products, women petty traders who sell sago-based food products, several village headmen and officers in Mukah District Office. In the two research locations, the data collection technique utilized was semi-structured interviews, observation and informal conversation. In addition, an interview was also conducted with the officials of Crop Research and Application Unit (CRAUN), a research office on sago palm tree and sago-based food product located in Kuching, Sarawak.

\section{Overview of the Study Location}

Melanau is the fifth largest indigenous group in Sarawak after the Iban, Chinese, Malays and Bidayuh. In Mukah Division, there are five major areas of sago palm, namely Oya-Dalat, Mukah, Pusa-Saratok, Igan and Balingian (Chew, Isa \& Mohayidin, 1998). Majority of the people are smallholder sago farmers and fishermen especially those that lives in the coastal areas of Oya, Matu, Mukah and Daro. Figure 2, illustrates the coastal Melanau settlement where sago production is very common. According to the 2010 Population Census of Malaysia, the total Melanau population is 123,410 in which they make up only $6 \%$ of the total population in Sarawak. 


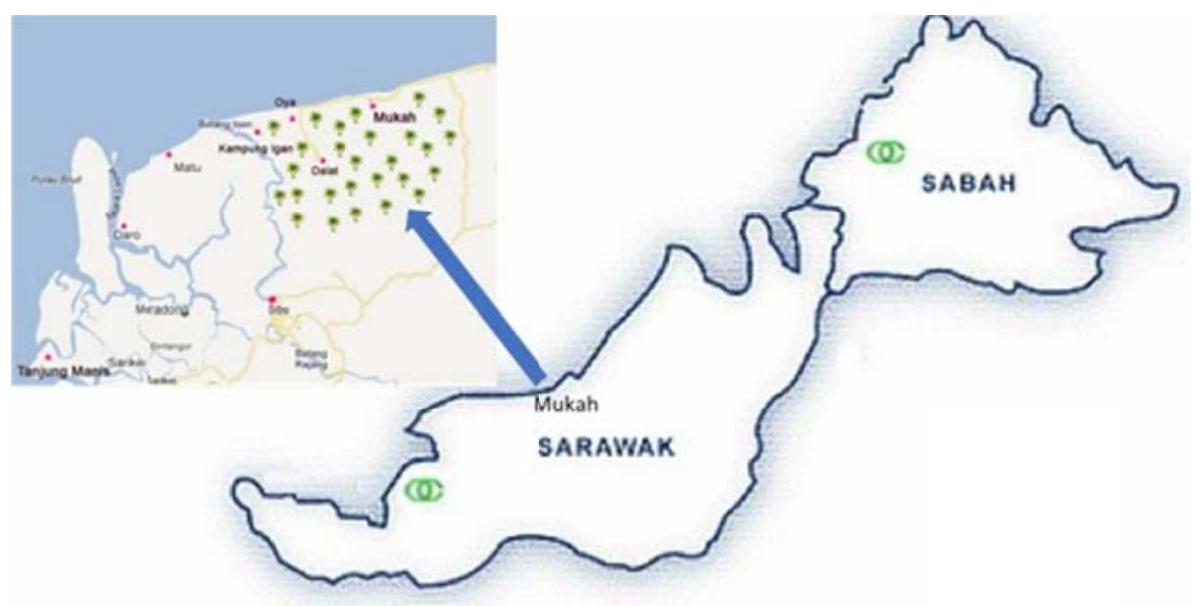

Figure 2. The Coastal Melanau Settlement and Sago Plantation Area.

\section{Historical Background and Development of Sago Palm}

Sago palm (Metroxylon sagu) is indigenous to Southeast Asia (Sasaoka, Laumonier \& Sugimura, 2014). It can be found in abundance in Indonesia, Papua New Guinea and Malaysia (Ahmad, 2014; Scaglion, 2017). The sago palm normal height is around 12-18 meters (Shin \& Collins, 2015). A tall sago palm is desired because the source of income is based on the trunk which will be cut into sections with approximately one meter in length for each section.

The rural dwellers, especially the Melanau who are mostly found in the northwest coastal communities of Sarawak with boundary streching from Rejang Delta to Bintulu are familiar with the farming, processing and use of sago. The starch extracted from its trunk is traditionally consumed by the Melanaus as a most prefered staple food beside rice, in the form of sago pearls or biji sagu (in Malay language) or saguk (in Melanau language). Sago starch has also been traded for over four centuries as export commodity to Brunei, a neighbouring country to Malaysia for cooking purposes. For example, in 1907 it was reported that Sarawak exported 20,388 tonnes of sago from Mukah and Oya areas worth $\$ 964,266$ (Baring-Gould \& Bampfylde, 2007). Since the early 19th century the revenue from sago export has made rural Melanau farmers prospered (Amir, 2015). However, the export of the commodity did not show tremendous increase compared to other Sarawak's export commodities. For example, In 2012, Sarawak exported 47, 849.29 metric tonne of sago products worth \$86, 345,004 (Sarawak Agricultural Statistics, 2013). At present, sago export has yet to make a significant impact on Sarawak economy beside other significant commodities including timber, palm oil, rubber and pepper.

\section{Sago Commercialization Development Program: Lack of Impact on Male Farmers' Roles?}

It is widely acknowledged in the literature relating to gender and rural livelihood that there is a need for active gender participation in food production and marketing (Sunderland et al., 2014). This is highly important for communities who mostly rely on agriculture as their means of livelihood. However, little is known about how initiated agricultural commodity commercialization programs can impact on gender roles in the Melanau communities of Sarawak, Malaysia. The location and climatic condition of where the sago trees are propagated on the Borneo Island showed high potential for it to be cultivated in large commercial quantities even beyond the current 50,000 hectares of land in use which can be a great source of income (Chew et al., 1999). It is in close proximity with Indonesia where sago is also cultivated on about 2 million hectares of land (Koonlin, 1980; Karim, Tie, Manan, \& Zaidul, 2008). With this great potential there is still impending concerns over the yield of sago which is inconsistent and low.

In promoting the value of sago, the crop is given an image of "the 21st Century Crop" which is spearheaded by the State Government of Sarawak to promote greater sago yield in both quantity and quality. Both the Federal and Sarawak governments have continuously provided various assistance to the industry and farmers in terms of research, equipments, promotions, farm clearance and management. One of the strategies initiated by the government was the Land Custody and Development Authority (LCDA) which introduced the Sago Smallholder Satellite Estate Development Program (SSSED). It is a land consolidation program which is designed to promote estate-like sago plantation. The program is expected to attract smallholders to join in order to increase the yield. According to one of the officers interviewed:

Agriculture statistic showed that smallholders' yield is one tonne per hectare in a year which is very low. We estimated that farmers who participate in plantation scheme should be able to produce 50 tonnes per hectare.

The program provides the smallholders with expertise and knowledge built by the agency in managing the farmers' sago plantation by introducing modern system of farming. The SSSED program provides the service for farmers without any cost within the first five years. However, despite giving such service, farmer \#5 mentioned that:

"I don't engage in SSSED program. I am satisfied managing my own farm"

SSSED is yet to receive much encouraging response, instead farmers have divided opinions on whether to join the 
program or refuse the offer. According to (farmer \#1) interviewed, he specifically expressed his disapproval of the plantation scheme because the model of sago farming introduced by SSSED is a replica of the palm oil plantation where the latter requires more attention, fertiliser, good drainage system, weeding and clearing of old leaves. He claimed that sago farming is the opposite of palm oil plantation. For instance, SSSED farming standard requires building of solid drainage system whereby traditional way of farming sago does not require this. In addition, (farmer \#8) also have some reservations as he did not agree with the SSSED's opinion on the clearance of surrounding area before planting sago trees. He said that:

"Sago tree can live alongside with other plants or weed." We don't have to clear the surroundings."

The study argued that these farmers' voices of disapproval relate to the changes in farming practices which has been embedded in their daily lives where they have full control of their farms. The implication of this for them is that, if the smallholder sago farmers join SSSED, the agency will be in total control and it will determine their farming practices. Hence, the autonomy they enjoyed on the land they owned may be restricted. Since peasant society operates in a natural environment, such form of control will disrupt farmers' everyday task. These means that farmers will no longer have control of certain farming practices which has been transferred to them for generations.

\section{Result and Discussion}

\subsection{Gender Roles and Sago Commercialization: What Impact?}

To understand the impact of sago crop commercialization on gender roles, this study investigates the roles of men and women in the sago sector. The focus capitalized on the use of gender relations framework which critically examines gender division of labor, control of resources which includes income generation and household decision making. As The study has argued earlier, their farming practices are embedded in value and norms of the community. In Malay language, the 'smallholders' are commonly referred to as pekebun or farmers and penanam or cultivators where these words can be used interchangeably when addressing smallholder farmers in the sago, rubber and oil palm sectors. Evidence from the fieldwork revealed that Melanau smallholder sago farmers feel more comfortable when addressed as pekebun balau (sago farmer). The reason is that they felt they do not cultivate the sago tree, instead they inherit the tree from their past generations since sago trees are reproduce from its suckers.

More importantly, sago farming is traditionally and still regarded as part-time job. In terms of working days, normally farmers work two to three days in a week. In addition, they will not work in their farm if there is death in the village or if they receive 'a bad sign'. If framers ignore the sign, they believe that they will receive trouble later. One of the farmers shared the cultural of sago farming, she said:

"Normally we work for three days on our farms. If there are unpleasant signs in the jungle which serves as signal to us that something is wrong and we need to be careful or cancel our working day i.e. a weird smell which signifies death of a villager or when a snake lies down horizontally or when a bird perches on the ground."

Despite the bright future of the sector, the younger generation is not showing interest in carrying on with the occupation of sago farming. This is due to the exposure through education, migration and inter-marriage. The research findings revealed that the majority of smallholder sago farmers are at the older age; either they are originally farmers or become smallholders after retired from working in other sectors. However, many of them work with their spouses and hired lumberjack for the job of felling the trees and send them to the mills. This qualitative data is supported by a survey of 308 farmers in Mukah where 65.9\% smallholders are in the age bracket of 55 and above. (Figure 3). The older farmers who reach 60 or 70 years old are normally engage in lighter roles such as weeding and pruning. Meanwhile felling trees which is a heavier task is given to hired lumberjacks.

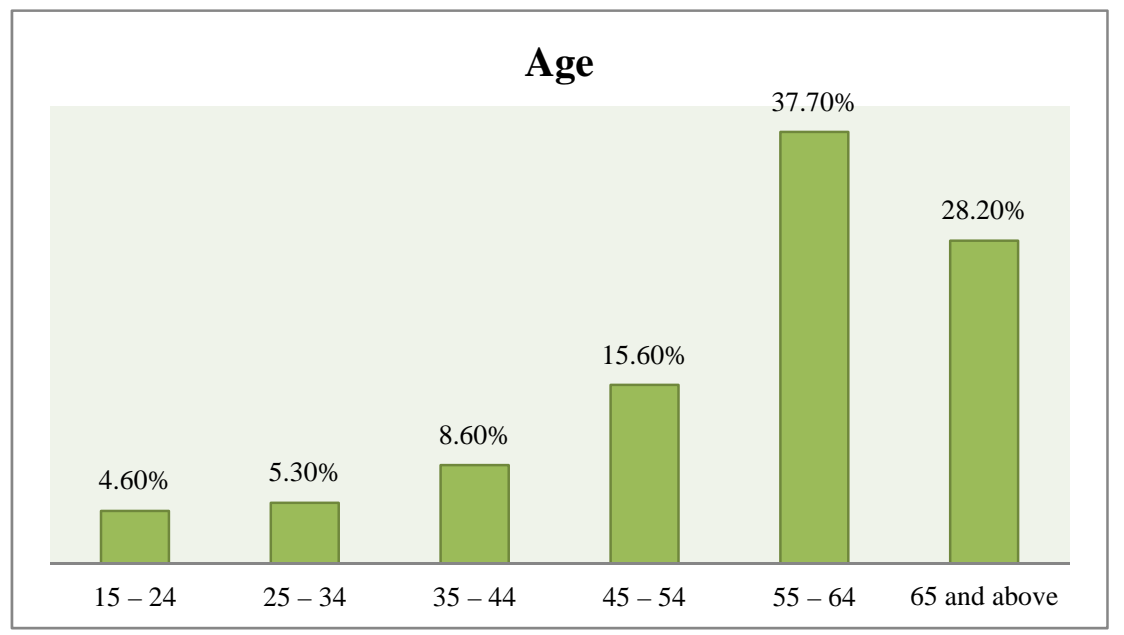

Figure 3. Melanau Sago smallholders’ age bracket (source: Awang Hamdan, Yaakub, Mohamad Naim, 2017) 


\subsection{Control and Ownership of Sago Farm Lands \& Household Decision Making}

As seen in many rural communities, men are considered as heads of households and decision makers. They always take control of the land used for agricultural production and every decision pertaining the utilization and management of land rests with them as long as they are still competent and alive (Villamor, et al., 2014). In the Melanau communities, men and women can own sago farm lands either by purchase or inheritance and it is also transferable from generation to generation. The sago farm owners are mostly regarded as the smallholder sago farmers and they are mostly men and breadwinners of their families. Usually, the men dominate the cultivation and management of sago farm lands and they also determine the marketing strategy and distribution channel of sago logs to factories that process the starch. Although women also own sago farm lands mostly by inheritance but one interesting fact is that Melanau women relinquish the control of their farm lands to their husbands or they jointly manage it as a family business. It is due to their marital relationships may allow a woman to benefit from her husband's assets and vice-versa. In this case, women are unable to stand by their decision regarding their farmland should they have different opinions.

\subsection{Division of Labour}

According to GLOPP/ILO (2008) gender division of labor is the way work is divided between men and women based on their gender roles. Sago production is tedious and labor intensive. The entire value chain of its production requires extra labor which is sometimes beyond the capacity of what a husband, or husband and wife alone can handle especially in the aspect of harvesting and processing of the sago palm. In this situation, the husband, wife, other family members and short term employees are required. It is customary, the responsibility of the husband being the head of household, to determine who and who within and outside the family circle should participate in the sago production. In Mukah and Dalat, it was discovered that cultural norms and values played important roles in gender division of labour. According to the tradition, men usually take responsibility of tasks that needs more strength and higher physical effort such as pruning, cutting and pushing of logs, steering and maintaining of boat as well as manual debarking. These are some of the activities that require special skills and the agencies should take responsibility to train smallholder sago farmers on better methods of carrying out all these tasks. The men are also saddled with the responsibility of seeking buyers of their sago logs, making business contacts regarding general logistics and transportation to sago mills.

The tasks are not exclusively carried out by the men as women also assist in less physical intensive activities such as weeding, making simple drainage, pushing of log and extraction of sago starch for household utilization or domestic markets. In Mukah and Dalat, when men are busy on the farmlands, women would engage in household activities such as cooking, cleaning and taking care of children which is culturally constructed as women's responsibilities. They also participate in other agricultural activities as mentioned by female smallholder when she said: "I plant pumpkin, yam, corn, cucumber and pineapple." For the women who own sago farms, they also face time management constraints, they don't usually have the time to efficiently participate in innovative sago production and processing trainings organized by the government and this further hinders them from attaining commercialization level.

\subsection{Income Generation and Access to Financial Resources}

For the women, they process sago flour into the Melanau's traditional staple food known as sago pearls which is produced either for consumption or commercial purposes. Not only that, they also produce other food from sago such as tebaloi (sweet, crispy cracker), tepung lemantak (wet sago starch flour) and tumpik (sago pancake). However, majority of the women do not process sago pearls for consumption and they have to buy sago products from other women when they are short of supply. For those women who produce in large quantities, it can be a source of income for them to supplement their household expenditures. The process of making sago pearls is very tedious and requires up to 10 hours in most cases to process. These include mixing sago flour with desiccated coconut (which is prepared a day earlier), coconut milk and paddy husks before it is shaped into tiny ball-shape pearls. Saguk is not roasted in the household kitchen, instead it is roasted in the makeshift hut called belanga with a hearth made from clay. In our visits to Mukah and Dalat, many households do not have belanga. Thus, the women who do not have their own belanga will always rent it from the other women to make their saguk whenever they are in need of it. The Melanau women can produce up to $60 \mathrm{~kg}$ ( 3 tins) of saguk at a time.

The income generated from sago logs is either managed by men or women. Majority head of household smallholders earn between RM500 to RM1,000 a month from their sago plantation from the logs mostly sold through agents. The finding is supported by a survey of 308 Melanau smallholders who are mainly male in Mukah by Awang Hamdan, Yaakub \& Hafizan, (2017). The lower income farmers have their 'safety net' when they typically consider their sago palm trees as their 'bank savings'. Sago palms trees will be harvested whenever the owner requires extra money for larger expenses such as wedding reception or paying their children education fees. Some of them are also involved in non-agricultural jobs such as small trading and commercial lorry driving. This means that the majority of smallholder sago farmers do not rely solely on sago production as their primary source of income.

In addition, some smallholder sago farmers also work as lumberjacks or penebang. In terms of earnings, they are the lowest earners. Women in the household of the latter category are more involved in income generating activities to supplement their household income. A female smallholder for instance, she had the experience of working in the sago farm land helping her husband. At the later age, she produced sago pearls for commercial purposes. When discussing issues related to income generated from sago business, many women interviewed in Mukah and Dalat noted that sago 
is adding to their family income and helping them to take care of their basic needs in their own little ways. For instance, informant \#12, a woman in Dalat, mentioned that:

"Sago pearls is my source of income, if I don't make sago pearl, I can't help to fend myself and my family"

While informant \#9, a smallholder woman, explained that she uses the income generated from sago production for "savings, other business capital and for personal expenses."

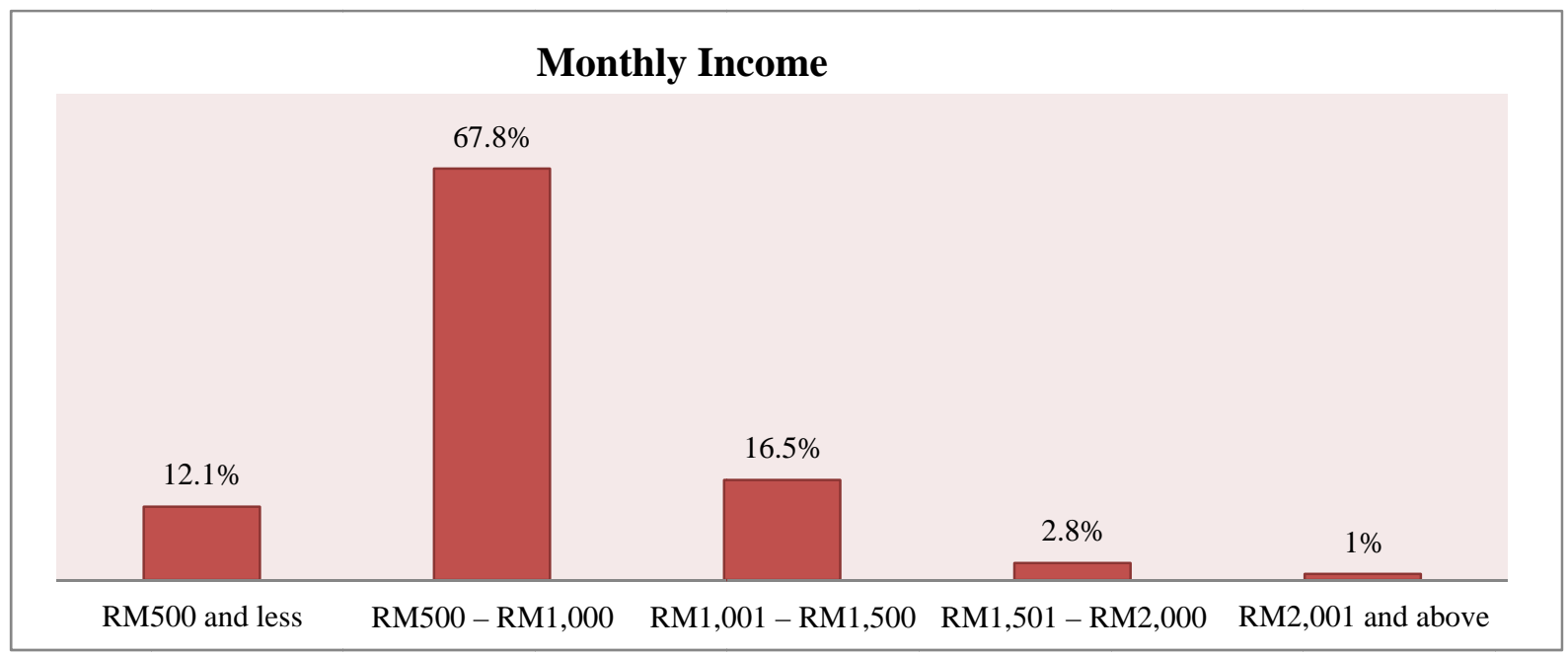

Figure 4. Melanau Sago smallholders’ Monthly Income

(source: Awang Hamdan, Yaakub, Mohamad Naim, 2017)

There is another characteristic of Melanau smallholders where some of them had worked at logging companies in Miri for many years during their younger age before they returned back to their villages. During those times, they were paid good salary but their working period is only four months in a year. This is confirmed by Amir (2015), when approximately 5 per cent of Melanau population in Dalat work as loggers in 1970s and 1980s. According to a male smallholder, initially, he did not possess any sago farmland but that change when he worked in a logging camp in Miri for some time to accumulate wealth. Later, he purchased a total of 12 hectares of farm where he planted sago palms while his wife, purchased 9.5 hectares of land with sago palms planted on it.

In the study, it was generally pointed out that women have limited access to financial resources to purchase land and equipment to boost their capacity for commercialization but they have adequate control of their little income, in the sense that they can buy whatever they need with their money provided they have it. Further, for the sago palms that belong to the women, not many of them utilize the income they generate from their previous production to continue and invest in cultivating sago. From observation, the Melanau people who participate in sago production and marketing do not usually crave for luxury lifestyle as they are mostly contented and happy with their ways of life. This observation is supported by a survey below (Figure 5) where more than 70\% household expenses are RM500 and less. Many farmers also don't really buy the idea of sago modernization initiative because they feel the traditional method still remains the best as well as their idea of sago farming as part-time job instead of full time job.

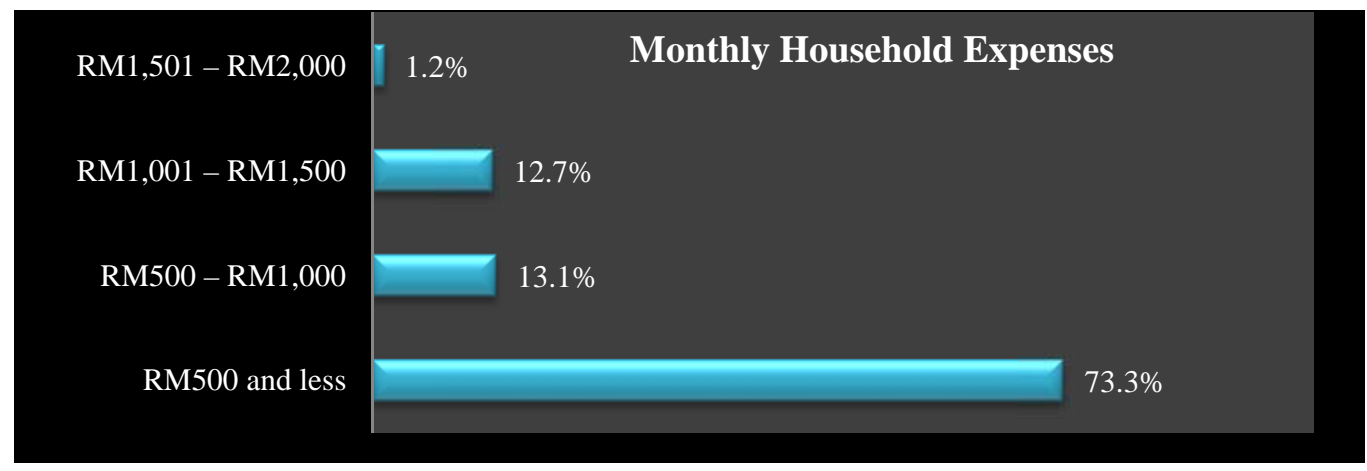

Figure 4. Melanau Sago Smallholders’ Monthly Income

(source: Awang Hamdan, Yaakub, Mohamad Naim, 2017)

\section{Conclusions and Implications for Policy}

This study has focused on the impact of gender roles on sago crop commercialization in the Melanau communities of Sarawak, Malaysia. The study has applied the qualitative research methodology guided by the gender relations framework to investigate the roles of men and women and the on-going commercialization programs designed by the 
government to develop the sago sector. On the one hand, it is undeniable that after more than three decades of sago development, research and commercialization programs supported by the government agencies have thrived. On the other hand, this research found that the respond from smallholder farmers are rather slow. In order to speed up the process, it is suggested that communication between related agencies and smallholders need to improve in order to avoid miscommunication in message dissemination (Naim, Yaakub \& Awang Hamdan, 2016).

The sago logs produced by the Melanau communities are for their consumption, domestic markets and export. Mostly, control and ownership of sago farmlands lies greatly with the men, even though, women can also own sago farm lands either by inheritance or purchase and can be transferred from generation to generation. However, women are less involved in decision making although they may have idea that support the sago commercialization program. In the aspect of division of labour, men and women participate in the sago farm lands regardless of who owns the farm land between them. Meanwhile, in the aspect of income generation, men control the income they generate from sago logs and the women control the income they generate from processing and selling of sago-based food. Further, it is commonly practiced that women own the income from farm land belongs to the women and managed by the men. Nevertheless, from all indications, Melanau women are very loyal to their husbands when it comes to issues related to the sago sector. Complementarity gender roles are clearly founded in explaining Melanau male and female gender relations. Moreover, Melanau people who participate in sago production and marketing don't usually crave for luxury as they are mostly contented and happy with their ways of life.

The fact that sago is traditionally cultivated and used as a staple food widely consumed locally by the Melanau people, aggravated the reluctance of farmers in giving away the traditional method of producing and processing for the modern method. In addition, the men and women are not so keen about wealth accumulation resulting in commercialization of sago is more difficult to achieve. At the same time, the attitude of younger generation who do not want to continue with the culture of cultivating sago serves as the major constraints that hinder the successful commercialization of sago in Sarawak, Malaysia. This empirical study confirmed that the majority of male farmers are still very much comfortable with their traditional method of cultivating sago. It also revealed that the indigenous Melanau dwellers have not showed keen interest in participating as competitors among sago mill owners and as such their gender roles of production still remains at sago farming and sago-based food processing level.

The research implication of this on commercialization of sago sector is that gender roles should be paid more attention so as to lift the industry from low production to a commercialized level. This includes intensifying effort to motivate the younger generation to consider participation in the sago industry. Empowering more men and women through trainings on land management is highly recommended so as to see commercialization as a beneficial tool that will increase income and improve welfare of household. The central problem associated with commercialization is that these smallholders viewed these changes distort their cultural norms and values in the sense that the indigenous knowledge they acquired and transferred among themselves from generation to generation could be replaced with modernized ideas coming from the commercialization program. No doubt, traditional norms and values can have serious influence on the acceptance of commercialization strategies. The interventions of the government through its many agencies may fail if they do not strategically blend the innovations with the cultural norms and values of the Melanau people. Therefore, it is recommended that the government should intensify their effort towards ensuring the capacity of men and women are built for the commercialization of the sago sector that take into consideration the socio-cultural aspect of norms and values of the Melanau smallholder sago farmers.

\section{Acknowledgement}

The research and findings presented in this paper, are the outcome of the collaborative fieldwork and review of literature carried out by the three researchers mentioned above in the title page, who are staffs of the Universiti Malaysia Sarawak. Funding for the impact of sago crop commercialization program on gender roles was provided by Tun Openg Chair, Centre for Sago Research, Universiti Malaysia Sarawak.

\section{References}

Ahmad, M. (2014). Farmer empowerment to increase productivity of sago (Metroxylon sago spp) farming. International Journal on Advanced Science, Engineering and Information Technology, 4(3), 129-133. http://dx.doi.org/10.1155/2016/8319542

Amir, J. (2015). Masyarakat Melanau di Sarawak (Melanau Society in Sarawak). Kuala Lumpur: ITBM \& PENA.

Awang Hamdan, D.A, Yaakub, A.N \& Mohamad Naim, H. (2017). Baseline study of sago smallholders in Mukah District, Sarawak. Paper Presented at International Conference on Development, Environment and Society 2017. Organized by Department of Development Studies \& Department of Anthropology and Sociology, Faculty of Social Sciences, UNIMAS at Riverside Majestic Hotel, Kuching, 16 \& 17 August 2017.

Baring-Gould, S. \& Bampfylde, C. A. (2007). A history of Sarawak under its two White Rajahs 1839-1908. Kuala Lumpur: Synergy Media.

Barton, H. (2012). The reversed fortunes of sago and rice, Oryza sativa, in the rainforests of Sarawak, Borneo. Quaternary International, 249, 96-104. https://doi.org/10.1016/j.quaint.2011.03.037

Belcher, B., \& Schreckenberg, K. (2007). Commercialisation of non-timber forest products: A reality check. 
Development Policy Review, 25(3), 355-377.

Carletto, C., Corral, P., \& Guelfi, A. (2017). Agricultural commercialization and nutrition revisited: Empirical evidence from three African countries. Food Policy, 67, 106-118. https://doi.org/10.1016/j.foodpol.2016.09.020

Carsten, J. (1997). The heat of the hearth: The process of kinship in a Malay fishing community. Oxford: Oxford University Press

Chew, T. A, Abu Hassan Md. Isa \& Mohd Ghazah bin Mohayidn, (1998). The sago industry in Malaysia: Present status and future prospects, In Z. Jin, Q. Liang, Y, Liang, X, Tan \& L. Guan (Eds.), Poceedings of the 7th International Working Conference on Stored-Product Protection, 199 Conference (pp. 1720-1728). Beijing, China: Sichuan Publishing House of Science and Technology.

Chew, T. A., Isa, A. H. B. M., \& Mohayidin, M. G. B. (1999). Sago (Metroxylon sagu Rottboll), the forgotten palm. Journal of Sustainable Agriculture, 14(4), 5-17.

Firth, W. R. (1966). Malay fishermen: their peasant economy. London: Routledge and Kegan Paul.

Forsythe, L., Posthumus, H., \& Martin, A. (2016). A crop of one's own? Women's experiences of cassava commercialization in Nigeria and Malawi. Journal of Gender, Agriculture and Food Security, 1(2), 110-128.

Harper, S., Zeller, D., Hauzer, M., Pauly, D., \& Sumaila, U. R. (2013). Women and fisheries: Contribution to food security and local economies. Marine Policy, 39, 56-63. https://doi.org/10.1016/j.marpol.2012.10.018

Hirschman, C. (2016). Gender, the Status of Women, and Family Structure in Malaysia. Malaysian Journal of Economic Studies, 53(1), 33-50.

Sarawak Agriculture Statistics 2013. Retrieved from http://www.doa.sarawak.gov.my/modules/web/pages.php?mod= webpage\&sub=page\&id=712

Karim, A. A., Tie, A., Manan, D. M. A., \& Zaidul, I. S. M. (2008). Starch from the sago (Metroxylon sagu) palm tree-properties, prospects, and challenges as a new industrial source for food and other uses. Comprehensive Reviews in Food Science and Food Safety, 7(3), 215-228. https://doi.org/10.1111/j.1541-4337.2008.00042.x

King, V. T. \& Wilder, W. D. (2003). The modern anthropology of South-East Asia. London \& New York: Routledge Curzon.

Koonlin, T. A. N. (1980). Sago production in southwest peninsular Malaysia. In Sago, the equatorial swamp as a natural resource: proceedings of the Second International Sago Symposium, held in Kuala Lumpur, Malaysia, September 15-17, 1979 (Vol. 1, p. 56). Kluwer Academic Pub.

Landa, J. T. (2014). Emergence of Sago Palms as Private Property: An Extension of Demsetz's Thesis of the Origins of Private Property. Man and the Economy, 1(1), 51-67.

Le, N. P. (2009). Changing of women's roles in production under a patriarchal society: Case study in a traditional craft village, northern vietnam. Asian Social Science, 5(3), 42-51. http://dx.doi.org/10.5539/ass.v5n3p42

Mashman, V. (1991). Warriors and weavers: A study of gender relations among the Iban of Sarawak, in V. H. J. Sutlive (Ed.), Female and male in Borneo: Contributions and challenges to gender studies, The Borneo Research Council, Inc., Williamsburg, VA USA, pp. 231-270.

Millstone, E., Thompson, J., \& Brooks, S. (2009). Reforming the global food and agriculture system: Towards a questioning agenda for the New Manifesto. STEPS Working Paper. 26 Brighton: STEPS Centre. http://steps-centre.org/wp-content/uploads/millstone-et-al-paper-26.pdf

Mohamad Naim, H., Yaakub, A. N., \& Awang Hamdan, D. A. (2016). Commercialization of Sago through Estate Plantation Scheme in Sarawak: The Way Forward. International Journal of Agronomy, 2016. http://dx.doi.org/10.1155/2016/8319542

Rubin, D., \& Manfre, C. (2014). Promoting gender-equitable agricultural value chains: Issues, Opportunities, and Next Steps. In Gender in Agriculture (pp. 287-313). Springer Netherlands.

Sasaoka, M., Laumonier, Y., \& Sugimura, K. (2014). Influence of Indigenous Sago-based agriculture on local forest landscapes in Maluku, East Indonesia. Journal of Tropical Forest Science, 75-83.

Scaglion, R. (2017). Sago: A Disparaged but Essential Food of the Abelam of Papua New Guinea. Food, Culture \& Society, 20(2), 201-215.

Scott, A. J. (2014). Cultural-products industries and urban economic development: prospects for growth and market contestation in global context. Urban Affairs Review, 39(4), 461-490.

Society of Sago Palm Studies (Ed.). (2015). The Sago Palm: The Food and Environmental Challenges of the 21st Century. Government Printing Office.

Sunderland, T., Achdiawan, R., Angelsen, A., Babigumira, R., Ickowitz, A., Paumgarten, F., \& Shively, G. (2014). Challenging perceptions about men, women, and forest product use: a global comparative study. World Development, 64, S56-S66. http://dx.doi.org/10.1016/j.worlddev.2014.03.003

Tsusaka, T. W., Orr, A., Msere, H. W., Homann-Kee Tui, S., Maimisa, P., Twanje, G. H., \& Botha, R. (2016). Do 
commercialization and mechanization of a "women's crop" disempower women farmers? Evidence from Zambia and Malawi. Paper presented at the Agricultural and Applied Economics Association. Boston, MA, $31^{\text {st }}$ July $-2^{\text {nd }}$ August 2016

van Eerdewijk, A., \& Danielsen, K. (2015). Gender Matters in Farm Power. Amsterdam: KIT. https://213ou636sh0ptphd141fqei1-wpengine.netdna-ssl.com/gender/wp-content/uploads/ publications/56fe4a6ced6cd_Gender\%20Matters\%20in\%20Farm\%20Power.pdf

Villamor, G. B., van Noordwijk, M., Djanibekov, U., Chiong-Javier, M. E., \& Catacutan, D. (2014). Gender differences in land-use decisions: shaping multifunctional landscapes?. Current Opinion in Environmental Sustainability, 6, 128-133. https://doi.org/10.1016/j.cosust.2013.11.015

Whatmore, S. (1991). Farming women: Gender, work and family enterprise. London: McMillan Academic \& Professional LTD.

Winzeler, R. L. (1974). Ethnic Complexity and Ethnic Relations in an East-Coast Malay Town. Southeast Asian Journal of Social Science, 2(1/2), 45-61.

\section{Copyrights}

Copyright for this article is retained by the author(s), with first publication rights granted to the journal.

This is an open-access article distributed under the terms and conditions of the Creative Commons Attribution license (http://creativecommons.org/licenses/by/4.0/). 